\title{
CHARACTER BUILDING DI ABAD 12 MASEHI: KAJIAN DAN ANALISIS PENDIDIKAN AKHLAK DALAM KITAB TA'LIM MUTA'ALIM
}

\author{
Binti Su'aidah Hanur a, 1 \\ ${ }^{a}$ Sekolah Tinggi Agama Islam Badrus Sholeh Purwoasri Kediri \\ ${ }^{1}$ freeda0740@gmail.com
}

\begin{tabular}{l}
\hline Informasi artikel \\
\hline Received : \\
Agust 15, 2018. \\
Revised : \\
Agust 27, 2018. \\
Publish : \\
September 09, 2018. \\
Kata kunci: \\
Pendidikan, Pendidikan \\
Akhlak, Kitab Ta'lim \\
Al-Muta'alim. \\
\hline
\end{tabular}

Keywords:

Education,

Moral

education,

Ta'lim

Muta'alim

book.

\begin{abstract}
ABSTRAK
Sejalan dengan pesatnya perkembangan ilmu pengetahuan dan tekhnologi, diperlukanlah pengembangan pendidikan yang sesuai dengan tuntutan perkembangan zaman, dengan mempertimbangkan aspek-aspek pengaruh positif dan negatif. Proses pendidikan yang mengedepankan akhlak atau nilai-nilai etik sebagaimana diatas rupanya mendapat perhatian serius oleh tokoh pendidikan abad ke-12 M, yaitu Az-Zarnuji. Artikel ini mengupas tentang pendidikan akhlak sebagaimana tertuang dalam kitab Ta'lim Al-Muta'alim dimana pada abad 21 ini lebih dikenal dengan nama pendidikan karakter.
\end{abstract}




\section{PENDAHULUAN}

Pendidikan sebagai bagian dari peradaban manusia, mau tidak mau pasti akan mengalami perubahan dan perkembangan. Akan tetapi realita pendidikan akhir-akhir ini menunjukkan perubahan dan pemandangan yang kontras, dimana guru hanya sebagai "pentransfer ilmu" layaknya robot, dan siswa sebagai "penerima" layaknya robot pula. Dan akhirnya menjadi suatu tatanan "mekanis" bagai mesin. Bahkan selain itu masalah akhlak juga kurang diperhatikan, baik akhlak terhadap guru, akhlak terhadap sesama murid. Maka jangan heran ketika Az-Zarnuji mengatakan: banyak dari sebagian pelajar yang sebenarnya mereka sudah bersungguh-sungguh menuntut ilmu, namun mereka tidak merasakan nikmatnya ilmu, hal ini disebabkan mereka meninggalkan atau kurang memperhatikan etika (akhlak) dalam menuntut ilmu.

Oleh sebab itu, kondisi pendidikan yang demikian mendorong kita untuk membangun cara pandang (worldview) baru dalam pendidikan yang tidak hanya berorientasi pada ilmu pengetahuan (knowledge oriented) dan keterampilan (skill oriented), namun juga berorientasi pada nilai (values oriented). Karena proses pembelajaran yang menekankan pada nilai-nilai akhlak (kejujuran, keharmonisan, dan saling menghargai) adalah hal yang tidak bisa dikesampingkan, bahkan dielakkan.

Proses pendidikan yang mengedepankan akhlak atau nilai-nilai etik sebagaimana diatas rupanya mendapat perhatian serius oleh tokoh pendidikan abad ke-12 M, yaitu Az-Zarnuji. Dia telah menyusun kitab Ta'limul Muta'allim yang mana didalamnya sarat dengan akhlak atau nilai-nilai etik dan estetik dalam proses pembelajaran. Kitab ini telah dijadikan referensi bagi santri di sebagian besar pondok pesantren di nusantara. Adapun nilai akhlak tersebut tampak pada pemikiran Az-Zarnuji tentang 
relasi dan interaksi guru dengan murid, murid dengan murid, bahkan murid dengan lingkungan sekitar(Fathiyah, 1986:77)

\section{PEMBAHASAN}

Kitab Ta'lim al-Muta'allim, merupakan sebuah kitab panduan pembelajaran (belajar dan mengajar) terutama bagi para murid, berisi muqaddimah dan mempunyai 13 fasl (bagian). Dalam muqaddimahnya, Az-Zarnuji mengatakan bahwa pada zamannya, banyak sekali para penuntut ilmu (thalibu al-ilmi) atau murid yang tekun belajar akan tetapi tidak mampu untuk memetik manfaat dari ilmu tersebut (mengamalkan dan menyebarkannya). Menurutnya hal ini terjadi karena peserta didik sudah meninggalkan persyaratan yang harus dipenuhi oleh setiap penuntut ilmu.

Adapun didalamnya terdapat beberapa konsep pendidikan yang sangat erat kaitannya dengan pendidikan sebagai transfer nilai (value) dan bukan hanya merupakan transfer ilmu pengetahuan (intellectual) dan keterampilan (skill). Diantara konsep transfer nilai tersebut adalah sebagai berikut:

\section{Akhlak merupakan sarana utama dalam pendidikan}

Kitab Ta'limul Muta'allim, merupakan panduan pembelajaran (belajar mengajar) terutama bagi murid. Tertulis dalam muqaddimah, Az-Zarnuji mengatakan bahwa pada zamananya, banyak sekali para penuntut ilmu (murid) yang tekun belajar namun tidak bisa mendapatkan memetik manfaat dari ilmu tersebut (mengamalkan serta menyebarkannya). Hal ini terjadi karena peserta didik meninggalkan persyaratan yang harus dipenuhi, sehingga mereka tidak berhasil. Az-Zarnuji dalam muqaddimahnya mengatakan bahwa kitab ini 
disusun untuk meluruskan tata cara dalam menuntut ilmu. Adapun dari fasl 1 sampai 13, Az-Zarnuji memberikan solusi tentang cara-cara menuntut ilmu.

Menurut Az-Zarnuji pendidikan akhlak adalah menanamkan akhlak mulia serta manjauhkan dari akhlak yang tercela dan mengetahui gerak gerik hati yang dibutuhkan dalam setiap keadaan, ini wajib diketahui seperti tawakkal, al-inabah, taqwa, ridha, dan lain-lain. Akhlak adalah sifat-sifat manusia untuk bermu'amalah dengan orang lain. Sebagaimana yang disebutkaan Ibnu Hajar Al-Asqalani yang dinukil dari Al-Qurtubi bahwa akhlak adalah sifat-sifat manusia untuk bermu'amalah dengan orang lain, baik sifat terpuji maupun sifat tercela. Az-Zarnuji juga berpendapat bahwa ilmu itu memuliakan pemiliknya, karena ilmu adalah perantara kebaikan dan ketaqwaan untuk mengangkat derajat disamping penciptanya dan kebahagiaan yang abadi, ilmu sebagai perantara untuk mengetahui sifat-sifat manusia seperti: takabbur, tawadhu, lemah lembut, 'iffah, isrof (berlebih-lebihan), bakhil (pelit), jubn (pengecut), maka dengan ilmu tersebut manusia akan bisa membedakan mana yang mulia dan mana yang tercela.

Kemudian belajar menurut Az-Zarnuji adalah bernilai ibadah, dan dapat mengantarkan seseorang untuk memperoleh kebahagiaan duniawi dan sejalan dengan konsep pemikiran para ahli pendidikan, yaitu menekankan bahwa proses belajar mengajar diharapkan mampu menghasilkan ilmu yang berupa kemampuan pada tiga ranah, yang mana menjadi tujuan pendidikan atau pembelajaran, baik ranah kognitif, afektif, maupun psikomotorik. Dan ukhrawi menekankan agar belajar adalah proses untuk mendapatkan ilmu, hendaknya diniati untuk beribadah. Artinya, belajar sebagai manifestasi 
perwujudan rasa syukur manusia sebagai seorang hamba kepada Allah Swt. yang telah mengaruniakan kepada kita akal.

Lebih dari itu, hasil dari proses belajar mengajar yang berupa ilmu (kemampuan dalam tiga ranah tersebut), hendaknya dapat diamalkan manusia, karena buah ilmu adalah amal. Pengamalan serta permanfaatan ilmu hendaknya selalu dalam koridor keridhaan Allah Swt. yakni untuk mengembangkan serta melestarikan agama Islam dan menghilangkan kejahilan, baik pada dirinya maupun orang lain. Inilah buah dari ilmu yang menurut Az-Zarnuji akan dapat menghantarkan kebahagiaan hidup di dunia maupun akhirat kelak.

\section{Guru}

Guru dianggap sebagai unsur yang mendasar dalam pembelajaran, dengan segala keteguhan, kesungguhan, dan segala kesabarannya akan sangat berpengaruh pada pendidikan, karena pendidikan merupakan tanggung jawab yang dipikul oleh seorang guru sebagai amanah yang akan dipertanggungjawabkan di depan Allah kelak, maka dengan menjalankan amanah tersebut harus sesuai dengan apa yang dianjurkan oleh Allah Swt.

Dalam hal ini, Az-Zarnuji mengatakan bahwa para guru harus memiliki sifat yang terpuji. Para guru di syaratkan memiliki sifat wara', memiliki kompetensi atau kemampuan dibanding muridnya, dan lebih tua usianya dari pada muridnya. Kemudian disamping itu, Az-Zarnuji juga menekankan pada kedewasaan, baik kedewasaan ilmu ataupun umur bagi seorang guru tersebut. Hal ini senada dengan pernyataan Abu Hammad Hanifah ketika bertemu 
dengan Hammad, seraya berkata: "Aku dapati Hammad sudah tua, berwibawa, santun, dan penyabar. Maka aku menetap disampingnya, dan akupun tumbuh dan berkembang”.

Para ilmuwan, sastrwan, dan filosof, telah memberikan nilai yang terhormat dan menempatkan posisi strategis bagi para pelaku pendidikan. Sebagaimana dikatakan oleh Al-Ghazali yang kemudian dikutip oleh M. Athiyah Al-Abrasyi: "Siapa yang memperoleh ilmu pengetahuan dan yang mengambil daya guna untuk kepentingan dirinya, kemudian mentransformasikan untuk orang lain, maka orang itu ibarat matahari yang bersinar untuk dirinya dan orang lain".

Dalam kitab Ta'limul Muta'allim, pertama guru berperan membersihakan, mengarahkan, dan mengiringi hati nurani siswa untuk mendekatkan diri kepada Allah dan mencari ridha-Nya. Dengan kata lain dapat disimpulkan bahwa ini adalah dimensi sufistik. Kedua adalah peran pragmatik. Dalam artian, guru berperan menanamkan nilai-nilai pengetahuan dan keterampilan kepada muridnya. Selain itu, guru juga memilihkan ilmu apa yang harus didahulukan dan diakhirkan, beserta ukuran-ukuran yang harus ditempuh dalam mempelajarinya.

\section{Peserta Didik}

Unsur selanjutnya yang memegang peranan penting dalam pendidikan adalah anak didik. Anak didik adalah manusia yang akan dibentuk oleh dunia pendidikan. Ia merupakan objek sekaligus subjek, yang mana tanpa keberadaannya mustahil proses pendidikan akan berjalan. 
Dalam hal ini Az-Zarnuji lebih mengaksentuasikan pada kepribadian atau sikap dan moral yang mulia, yang sangat diperlukan oleh para pelajar. Adapun kepribadian yang harus dimiliki tersebut sebagaimana dikatakan AzZarnuji, adalah setiap murid harus mempunyai sifat-sifat tawadhu', 'iffah, yaitu sifat yang menunjukkan harga diri yang menyebabkan seseorang terhindar dari perbuatan yang tidak pantas dilakukan, kemudian sifat tabah, sabar, wara' (menjauhkan diri dari dosa, dari maksiat, dari perkara syubhat), serta tawakkal, yaitu menyerahkan segala perkara hanya kepada Allah.

Kemudian Az-Zarnuji juga menekankan agar dalam menuntut ilmu, setiap murid hendaknya mencintai ilmu, hormat kepada guru, keluarganya, sesama penuntut ilmu, sayang kepada kitab dan menjaganya dengan baik, bersungguh-sungguh dalam belajar dengan memanfaatkan waktu, tekun dalam menuntut ilmu serta mempunyai cita-cita tinggi dalam menuntut ilmu pengetahuan. hal ini senada dengan pernyataan Imam Al-Gahazali dalam kitab Ihya Ulumuddin, yaitu: "kewajiban setiap guru ialah terlebih dahulu membersihkan jiwa dan akhlak yang tercela serta sifat-sifat yang hina, mempersempit kesibukan dengan keduniawiaan.

\section{Kurikulum}

Selain guru dan murid, faktor penting dalam pendidikan adalah faktor kurikulum. Karena kurikulum merupakan faktor yang sangat penting dalam proses pendidikan di suatu lembaga pendidikan. Mata pelajaran yang harus diketahui dan dihayati oleh anak didik harus ditetapkan dalam kurikulum. Materi pelajaran yang akan disajikan kepada anak didik, haruslah dijabarkan 
terlebih dahulu dalam suatu kurikulum. Dengan demikian, dalam kurikulum akan tergambar dengan jelas dan terencana sebagai tujuan pencapaian target pembelajaran.

Dalam masalah kurikulum, Az-Zarnuji tidak menjelaskan secara terperinci. Namun dalam kitab Ta'limul Muta'allim dijelaskan tentang pelajaran yang harus dipelajari dan urutan ilmu yang dipelajari. Secara filosofis, Az-Zarnuji memberikan uraian-uraian mata pelajaran sebagai kandungan dalam kurikulum seperti panjang pendeknya durasi suatu pelajaran, pelajaran mana yang harus didahulukan dan diakhirkan, pelajaran yang wajib dan yang haram dipelajari.

Adapun materi pelajaran hendaknya mengambil pelajaran baru yang dapat dihapalkan dan dipahami setelah diajarkan oleh guru. Selanjutnya setiap harinya ditambah sedikit demi sedikit sehingga pada suatu saat akan menjadi kebiasaan. Jika ukuran pelajaran yang diberikan sukar dan diatas kemampuan murid, maka ia akan sukar untuk memahaminya, yang mana ini akan mengakibatkan kehilangan kepercayaan kepada diri sendiri, karena ia tidak memperoleh santapan jiwa yang sesuai untuk pertumbuhan akalnya dan untuk kemajuan. Pernyataan Az-Zarnuji diatas senada dengan pendapat pakar pendidikan modern yang menyerukan pembawaan anak didik harus diperhatikan dan dijadikan sebagai dasar dalam mengajar.

Untuk mengimplementasikan kurikulum secara praktis, Az-Zarnuji memberi arahan hal-hal yang harus dikerjakan, seperti sifat wara' atau menjauhkan diri dari dosa, dari maksiat, dari perkara syubhat dalam belajar, 
pemilihan waktu belajar dan mengajar yang tepat, dan ukuran serta batasan materi pelajaran. Bagi Az-Zarnuji, bukan masalah banyak dan sedikitnya materi, tetapi yang lebih penting adalah materi yang yang lebih mendesak dan diperlukan (ilmu al-hal). Ini berarti, Az-Zarnuji memiliki pandangan bahwa kurikulum yang dipelajari harus relevan, yaitu sesuai dengan kebutuhan peserta didik (murid). Hal ini sudah tentu harus disesuaikan dengan kemampuan anak didik. Oleh karena itu, bahan yang diberikan adalah yang mudah terlebih dahulu, kemudian ketingkatan yang lebih sukar. Ini menunjukkan, bahwa materi yang diberikan harus sesuai dengan kematangan anak didik.

Dalam ta'limul Muta'allim Az-Zarnuji mengatakan bahwa proses belajar mengajar hendaknya dilaksanakan sesuai dengan perkembangan jiwa seseorang. Misalnya, pada usia kanak-kanak, aktivitas menghafal dengan cara perulangan harus diutamakan, hal ini karena pola piker anak didik masih bersih, dan anak-anak masih cenderung untuk meniru apa yang disampaikan oleh guru. Pada usia pendidikan menengah, anak didik mulai dikenalkan untuk memahami apa yang diajarkan oleh guru. Mata pelajaran bukan sekedar di hafal, tetapi juga harus difahami makna-makna yang terkandung didalamnya. Kemudian pada tahapan berikutnya, disamping menghafal dan memahami, anak didik juga harus aktif dan merefleksikan, serta kreatif untuk selalu bertanya. Lebih lanjut Az-Zarnuji mengatakan bahwa bertanya itu lebih baik dari pada menghafal selala satu bulan. Kemudian para pelajar hendaknya mencatat pelajaran-pelajaran yang telah diberikan oleh guru. 
Ada beberapa hal yang perlu digarisbawahi, yang mana berkaitan dengan atmosfir akademik dan nilai akhlak relasi antara guru dan murid sebagaimana dalam Ta'limul Muta'allim, yaitu pendidikan yang utama adalah berangkat dari hal-hal yang substansial, yakni masalah akhlak. Dengan kata lain, dari masalah substansial dan esensi ini akan melahirkan perform yang sejati.

\section{Pola Relasi antara guru dan murid}

Dalam sebuah pembelajaran hubungan guru dan murid menempati suatu hal yang sangat penting, perlu membentuk lingkungan yang didasari dengan keharmonisan antara guru dan murid, demi tercapainya tujuan belajar mengajar dengan baik, karena pendidikan adalah masalah pribadi yang perlu diperhatikan dan harus menjadi hubungan antara keduanya, begitu juga seorang murid harus mempunyai waktu yang cukup untuk mengambil manfaat pengetahuan dan sifat-sifat terpuji dari guru.

Pola hubungan atau relasi antara guru dan murid dalam Ta'limul Muta'allim sebagaimana dianjurkan Az-Zarnuji adalah semacam 'labolatorium' pembelajaran akhlak untuk relasi yang lebih besar. Relasi ini dijiwai oleh sifat-sifat sufi seperti tawadhu', sabar, ikhlas, penuh pengertian, dan saling menghormati.

Dengan demikian, harus ada hubungan ruhiyah yang baik antara guru dan murid, yaitu seperti hubungan bapak dan anak, jika seorang guru ingin berperan sebagai seorang bapak dalam pembelajaran, maka ia harus 
mempunyai sifat sempurna seperti bapak di dalam keadilan, kesabaran, mencintai bagi semuanya, lemah lembut ketika dalam memberikan peringatan, dan semuanya itu dilakukan atas dasar untuk membentuk suatu hubungan yang baik.

Disamping itu, bahwa dalam proses belajar dan mengajar ada hubungan yang bersifat ilmu-ilmu dasar pengajaran antara guru dan murid, dianjurkan seorang guru didalam kegiatan pendidikan wajib menjaga dan memperlakukan sama antara murid-muridnya.

\section{Metode pendidikan akhlak}

Berkaitan dengan metode pengajaran pendidikan akhlak, Az-Zarnuji mengemukakan tiga metode yang penting dalam pendidikan akhlak, di antaranya adalah:

\section{a. Metode pendidikan akhlak dengan nasehat}

Nasehat termasuk metode pendidikan Islam yang penting khususnya pendidikan akhlak, nasehat termasuk sebaik-baiknya metode pengajaran sehingga Az-zarnuji memasukkan nasehat, belas kasihan, dan menyayangi sebagai syarat yang harus dijiwai seorang guru, ini semua demi kebaikan anak didiknya, bukan untuk menghilangkan nikmat mereka.

Nasehat adalah sumber penjelasan tentang sesuatu yang haq dan baik, dengan tujuan menjauhkan anak didik dari kebatilan, serta menunjukkan suatu benar-benar bermanfaat, bukti nasehat yang benar yaitu bukan untuk diri sendiri atau mencari untuk dirinya sendiri. Dengan demikian seorang guru harus membersihkan diri dari sifat-sifat yang tercela 
dalam melaksanakan tugas pendidikan, sehingga apa yang disampaikan guru membekas dijiwa para anak didik. Disamping itu, metode ini memberi kesempatan luas kepada guru untuk menanamkan kebajikan, kemaslahatan, kemajuan masyarakat dan umat manusia. Guru harus berusaha memberi kesan yang baik dan mementingkan kemaslahatan kepada anak didiknya, hal ini menjadikan anak didik mudah menerima nasehatnya.

\section{b. Metode pendidikan akhlak dengan mudzakarah (saling mengingatkan)}

Selain itu, strategi pembelajaran aktif (active learning) lain adalah yang diusung Az-Zarnuji ialah strategi pembelajaran yang didalamnya mengandung unsur saling mengingatkan (mudzakarah). Metode ini memuat metode tausiyah, menyerukan kepada kebaikan dan melarang kepada kemungkaran. Maka Az-Zarnuji memberi arahan agar guru mempunyai sifat lemah lembut dan menjaga sifat pemurah, karena tujuan metode ini ialah menerangkan kebenaran dan kebaikan.

Mudzakarah ialah nasehat tentang kebaikan dan kebenaran dengan bentuk mengetuk hati dan membangkitkan untuk beramal, mudzakarah juga disebut suatu janji penasehat kepada yang dinasehati tentang maknamakna yang bisa membangunkan perasaan untuk bersegera untuk beramal soleh, serta taat kepada Allah dengan menjalankan perintah-Nya.

Az-Zarnuji juga memberi batasan kepada guru agar dalam mengingat kepada murid tidak melampaui batas karena dapat menyebabkan nasehatnya tidak diterima, sebaiknya guru sebelum menyampaikan tausiyahnya berfikir dengan cermat, memakai bahasa yang 
halus, dan cara-cara yang sesuai dengan mereka. Dengan demikian akan mencapa tujuan yang diinginkan. Az-Zarnuji juga menganjurkan kepada peserta didik menghabiskan waktunya untuk belajar dengan sungguhsungguh. Pada metode ini tampak bahwa Az-Zarnuji sangat menekankan akhlak guru maupun murid.

c. Metode akhlak yang lebih berorientasi kepada konsep wajib dalam belajar

\section{1) Tujuan dan niat belajar}

Sebagaimana dikatakan oleh Az-Zarnuji bahwa Niat adalah sangat penting dalam belajar, karena niat adalah jiwa dari segala tingkah laku orang. Disamping itu ada pula hadits yang mengatakan:

$$
\begin{aligned}
& \text { كم من عمل يتصور بصورة أعمال الدنياو يصير بحسن النية من أعمال الآخرة وكم من } \\
& \text { عمل يتصور بصورة أعمال الآخرة ثم يصير من أعمال الدنيا بسوء النية. }
\end{aligned}
$$

"Banyak sekali amal perbuatan yang bercorak amal perbuatan duniawi, tetapi karena baiknya niat menjadi amal perbuatna akhirat. Dan banyak sekali perbuatan yang bercorak amal perbuatan akhirat, tetapi menjadi perbuatan dunia karena jeleknya niat”.

Lalu niat seperti apa yang harus dimiliki oleh seorang penuntut ilmu?. Tujuan atau niat orang yang menuntut ilmu adalah mencari keridhaan Allah Swt. dan memperoleh kebahagiaan dunia dan akhirat, berusaha memerangi kebodohan pada diri sendiri dan orang lain, mengembangkan dan melestarikan ajaran Islam serta mensyukuri seluruh nikmat Allah Swt. 
Lebih tegasnya diungkapkan bahwa agar setiap orang yang hendak mencari ilmu atau menuntut ilmu jangan sampai keliru dalam menentukan niat dalam belajar, misalnya belajar diniatkan untuk mencari pengaruh, popularitas, mendapatkan kebahagiaan dunia atau kehormatan serta kedudukan tertentu, dan lain sebagainya. Tetapi bukan berarti bahwa manusia itu tidak boleh mengejar kenikmatan yang sifatnya duniawi. Boleh mempunyai niat untuk meraih kemuliaan, apabila dengan itu dimaksudkan untuk kepentingan amar ma'ruf nahi munkar (mengajak kepada perbuatan baik dan mencegah perbuatan yang tidak baik), melaksanakan yang hak dari kemuliaan agama. Artinya bahwa keinginan mencapai kemuliaan itu bukan untuk kepentingan dirinya sendiri, melainkan untuk kepentingan bersama.

Selain dara pada itu penuntut ilmu jangan sampai merendahkan diri dengan mengharapkan memperoleh sesuatu yang tidak semestinya, dan mencegah diri dari terlibat dalam hal-hal yang merendahkan dan meremehkan ilmu. Harga diri hendaknya selalu dijaga. Disamping itu dalam mencari ilmu harus tawadhu', perlu digaris bawahi bahwa tawadhu' adalah sifat yang ada ditengah-tengah antara sombong dan merendahkan diri.

\section{2) Bersikap wara' di waktu belajar}

Az-Zarnuji menganjurkan bahwa sekiranya bagi setiap penuntut ilmu itu bersikap wara', karena hanya dengan sikap wara' tersebut ilmunya akan berguna, belajar menjadi mudah dan 
mendapatkan pengetahuan yang banyak, lebih tegasnya lagi dijelaskan bahwa diantara sikap wara' tersebut juga menjauhkan diri dari golongan yang berbuat maksiat dan kerusakan, perut tidak terlalu kenyang, tidak banyak tidur dan tidak banyak bicara yang tidak ada gunanya, bahkan karena hati-hatinya Az-Zarnuji menganjurkan agar senantiasa menghindari dari makanan dari pasar, karena makanan pasar dikhawatirkan najis dan kotor.

\section{3) Mengambil faedah (al-Istifadah)}

Az-Zarnuji mengatakan bahwa yang dimaksud dengan metode istifadah ialah guru menyampaikan ilmu pengetahuan dan hikmahnya yaitu menjelaskan perbedaan antara perkara yang haq dan bathil dengan ucapan baik, sedang menurut Az-Zarnuji murid sebaiknya mengambil faedah sebanyak-banyak nya apa yang disampaikan oleh guru, dan sampai dia mengatakan setiap waktu dan tempat membawa pena dan mencatat sesuatu yang lebih baik selama ia mendengarkan guru secara terus menerus sehingga mendapatkan keutamaan dari gurunya.

\section{4) Tawakkal dalam mencari ilmu}

Menurut Az-Zarnuji sebaiknya sebagai seorang guru dalam mencari ilmu pengetahuan harus menanamkan sifat tawakkal dan tidak sibuk untuk selalu mendapatkan hal duniawi semata, karena dapat merusak hati yang menyebabkan sulit untuk mendapatkan akhlak yang mulia. Az-Zarnuji juga mensyaratkan agar setiap individu untuk sibuk 
dengan perbuatan-perbuatan yang baik dan mementingkan urusan ukhrawi. Hal ini merupakan perilaku akhlak yang harus dijiwai karena melaksanakan hak-hak kewajiban sesuatu akhlak yang mulia, hati yang selalu ingat kepada penciptanya adalah dari beberapa sebab yang dianjurkan dalam tawakkal haqiqi kepada Allah, tawakkal haqiqi ini sangat dianjurkan oleh Islam karena merupakan zhohirnya iman dan zhohirnya akhlak.

\section{KESIMPULAN}

Pendidikan akhlak yang ada dalam kitab Ta'limul Muta'allim sebagaimana diformulasikan oleh penggagasnya yaitu Az-Zarnuji memiliki nuansa sufistik peadagogik. Hal ini bisa dilihat pada landasan berfikir yang dibangun dari term-term tasawuf sebagai landasan utama. Konsep ridha, tawadhu, wara', ikhlas dan sabar merupakan kata kunci dalam proses pembelajaran. Konsep ini diimplementasikan dalam wilayah skala kecil sosial (guru, murid, hubungan antara guru dan murid itu sendiri, serta dalam kurikulum) sebagai laboratorium yang bernama pendidikan. Kemudian pendidikan akhlak yang digunakan Az-Zarnuji adalah metode nasehat, saling mengingatkan (tazakur), dan metode yang bersifat wajib dalam belajar (niat, wara dalam belajar, istifadah, tawakkal dalam belajar). Konsep ini juga diaplikasikan dalam wilayah skala kecil sosial pula, sebagai laboratorium yang dinamakan pendidikan.

Sehingga dengan demikian dapat disimpulkan bahwa pendidikan akhlak yang di gagas oleh Az-Zarnuji tidak hanya berorientasi pada ranah ilmu pengetahuan dan keterampilan, akan tetapi lebih dari pada itu, yaitu menggabungkan antara ilmu 
pengetahuan (intellectual), keterampilan (skill) dan nilai (value), dengan adanya sistem value ini kita tidak menjadikan guru hanya sebagai "pentransfer ilmu" layaknya robot, dan siswa sebagai "penerima" layaknya robot pula, dan akhirnya menjadi suatu tatanan "mekanis" bagai mesin. Akan tetapi lebih menjadikan mereka sebagai manusia utuh, dan akan melahirkan aktor-aktor intelektual yang berwawasan, serta mampu menghiasi kehidupan dengan keharmonisan dan ketentraman yang berlandaskan pada akhlak mulia.

\section{REFERENSI}

Burhanul Islam Az-Zarnuji. 1981. Ta'lim Muta'alim Thoriqul Ta'lim. Beirut: Marwan Qobani.

Hasan Sulaiman Fathiyah . 1986. Sistem pendidikan versi Al-Ghazali terj.Fathur Rahman . Bandung: Al-Maarif

Masud Abdurrahman..2007. Menggagas format pendidikan Non dikotomik..Yogyakarta: Gama Media

Muzzaki Akh. Kholilah..2017.Ilmu pendidikan islam . Surabaya: Kopertais IV press. Purwanti Eni ,dkk. 2017. Pendidikan karakter. Surabaya: Kopertais wilayah IV press. Peraturan Menteri Agama Republik Indonesia nomor 16 tahun 2010 tentang pengelolaan pendidikan Agama pada sekolah. 